\title{
Variasi Aeromonas Pada Ikan Sidat (Anguilla sp.) yang dilalulintaskan Melalui Bandar Udara Palu
}

\author{
IRMAWAN SYAFITRIANTO ${ }^{1}$, AMAL AQMAL ${ }^{2}$, MOHAMMAD NUR HALIK LANDE ${ }^{1}$ \\ ${ }^{1}$ Stasiun Karantina Ikan, Pengendalian Mutu dan Keamanan Hasil perikanan Kelas I Palu \\ J1. Garuda No 22, Palu, Sulawesi Tengah 94115 \\ email: wawancrab@kkp.go.id \\ ${ }^{2}$ Fakultas Pertanian, Universitas Bosowa, Makassar \\ J1. Urip Sumoharjo KM 04, Kec Makassar, Sulawesi Selatan 90231
}

\begin{abstract}
Central Sulawesi is a province produce eels (Anguilla marmorata) in Indonesia. Eels is the one commodity that has a high economic value. In the last years, eels trading traffic through the airport had increased. Fish health status to be one of the important issues in trade of eels. Genus Aeromonas is disease-causing pathogen on eels and as the etiologic agent responsible for a variety of infectious complications pathogenic bacteria. The purpose of this study is identify the various species of the genus Aeromonas on the eels which are traffic through Mutiara Sis Al jufri Airport Palu. This observation have been from April to December 2014. Specimens Anguilla sp. was obtained from supplier in the Palu city. Laboratory examination performed use conventional methods (Biochemistry) and performed in Microbiology Laboratory of Fish Quarantine Palu. The result showed from 396 eels have been identified, 128 of them are of the genus Aeromonas (32.32\%). Aeromonas were identified some species among other: Aeromonas sobria, Aeromonas hydrophilla, and Aeromonas caviae. A.sobria is higher percentage in April and August 2014 (57,14\%), A. hydrophilla in December 2014 (92,85\%), and A. caviae August 2014 (21,43\%). The existence of pathogenic bacteria in eels this should be a concern to prevent widespread dissemination through trade traffic.
\end{abstract}

Keywords: Aeromonas, eels, identify, Palu, traffic

\section{INTISARI}

Sulawesi tengah merupakan provinsi penghasil ikan sidat (Anguilla marmorata). Ikan sidat merupakan salah satu komoditas yang memiliki nilai ekonomi tinggi. Status kesehatan ikan merupakan isu penting dalam perdagangan ikan sidat (A. marmorata). Bakteri dari genus Aeromonas merupakan patogen penyebab penyakit pada sidat dan sebagai agen etiologi yang bertanggung jawab terhadap komplikasi infeksi patogen. Tujuan dari penelitian ini adalah untuk mengidentifikasi berbagai variasi spesies dari genus Aeromonas pada sidat yang dilalulintaskan melalui bandar udara Mutiara Sis Aljufri Palu. Penelitian dilakukan pada bulan April Hingga Desember 2014. Spesimen sidat diperoleh dari pengumpul yang ada di sekitar Kota Palu. Pengujian laboratorium menggunakan metode konvensional (biokimia) dilakukan di Laboratorium Mikrobiologi Stasiun Karantina Ikan Palu. Hasil penelitian menunjukan bahwa dari 396 sidat yang diuji, 128 diantaranya teridentifikasi Aeromonas (32,32\%). Spesies Aeromonas yang diidentifikasi antara lain: Aeromonas sobria, Aeromonas hydrophila, dan Aeromonas caviae. Presentase Aeromonas sobria tertinggi pada bulan April dan Agustus 2014 (57,14\%), A.hydrophila pada bulan Desember (92,85\%), dan A. Caviae pada bulan Agustus (21,43\%). Keberadaan bakteri patogen pada sidat menjadi perhatian untuk dapat dilakukan pencegahan terhadap penyebaran melalui lalulintas dan perdagangan.

Kata kunci: Aeromonas, identifikasi, lalulintas, Palu, sidat 


\section{PENDAHULUAN}

Ikan sidat (Anguilla sp.) merupakan salah satu komoditas perikanan yang memiliki nilai ekonomi tinggi. Provinsi Sulawesi Tengah merupakan salah satu provinsi penghasil ikan sidat terbanyak di Indonesia. Frekuensi pengiriman ikan sidat asal Provinsi Sulawesi Tengah yang dilalulintaskan melalui bandar udara Mutiara Palu terus mengalami peningkatan semenjak tahun 2010 hingga 2012. Tahun 2010 terdapat 748 kali pengiriman ikan sidat dan meningkat menjadi 1.158 kali pengiriman pada tahun 2012 .

Status kesehatan menjadi salah satu isu penting dalam pemasaran ikan sidat (Anguilla sp.) di Sulawesi Tengah. Salah satu persyaratan pasar yang harus dipenuhi oleh pemasok ikan sidat adalah bebas dari penyakit. Serangan penyakit pada ikan sidat merupakan salah satu faktor penyebab terjadinya kegagalan dalam budidaya dan mengakibatkan subsektor budidaya perikanan tidak dapat berkembang dengan baik.

Estimasi nilai kerugian ekonomi akibat penyakit pada budidaya jarang dilakukan, tetapi jika tetap dilakukan, hasilnya cukup mencengangkan. Sebagai contoh kerugian akibat terjadinya serangan penyakit bakteria (Edwardsiella tarda) pada ikan flounder Jepang (Paralichthys olivaceus) mencapai 487,9 milyar Won Korea pada tahun 2010. Menurut Nielsen dkk. (2001), bakteri Aeromonas hydrophilla pernah menyerang ikan-ikan cyprinid di Provinsi Zhejiang China pada tahun 1989 hingga 1993, selama kurun waktu tersebut estimasi kerugian mencapai 2200 ton ikan setiap tahunnya.

Agen penyebab penyakit pada ikan sidat (Anguilla sp.) adalah infeksi oleh virus, bakteri, parasit, dan jamur. Infeksi bakteri antara lain disebabkan oleh: Aeromonas spp., Vibrio spp., Pseudomonas sp. Kelompok bakteri dari genus Aeromonas merupakan bakteri yang dapat ditemukan di daerah perairan tawar, bersifat Gram negatif dan berbentuk batang (Gardenia dkk., 2010). Aeromonas spp. merupakan patogen, baik pada manusia maupun hewan (ikan, amfibi, reptil). Pada manusia, dapat menyebabkan gangguan gastrointestinal, infeksi dan luka pada usus halus serta berbagai infeksi lainnya.

Meskipun angka kematian yang disebabkan oleh Aeromonas tergolong rendah $(<10 \%)$ (Floyd, 2002), namun bakteri ini dapat menyerang ikan sepanjang waktu. Pada beberapa contoh, faktor yang berpengaruh diantaranya adalah stress. Stress menyebabkan ikan mudah terinfeksi bakteri. Keadaan stress juga dapat disebabkan oleh buruknya kualitas air, kepadatan yang berlebih, dan penanganan yang buruk.

Penelitian ini bertujuan untuk mengetahui variasi spesies dan frekuensi serangan bakteri genus Aeromonas pada ikan sidat yang dilalulintaskan melalui bandar udara mutiara Palu. Hasil penelitian ini dapat digunakan sebagai acuan dalam mencegah penyebaran penyakit ikan yang disebabkan oleh bakteri Aeromonas.

\section{METODE}

Studi yang dilakukan bersifat observasi, yakni dengan mengumpulkan spesimen sidat (Anguilla sp.), pengujian laboratorium, dan pengolahan data. Pengumpulan spesimen sidat dan pemeriksaan bakteri di lakukan pada bulan April hingga Desember 2014.

Spesimen uji ikan sidat (Anguilla sp.) diperoleh dari pengumpul di sekitar Kota Palu yang akan dilalulintaskan melalui bandar udara mutiara sis Aljufri, Palu. Tiap pengambilan contoh uji dicatat nama pengumpul, daerah asal, tanggal pengambilan contoh, dan gejala klinis.

Pengujian bakteri dilakukan menggunakan metode konvensional (Biokimia). Karakteristik yang diuji mencakup: pewarnaan gram, motilitas, katalase-oksidase, Indol, Ornithin, L arginin, Aesculin, OF, methylred (MR), Voges Proskauer (VP), L arabinosa, glukosa, TCBS, dan Rs agar. Hasil yang diperoleh kemudian diidentifikasi berdasarkan petunjuk Buller (2004). Data hasil pengujian diolah secara deskriptif dengan menggunakan program Microsoft excel 2013, yaitu dengan menghitung persentase bulanan ditemukannya Aeromonas pada ikan sidat (Anguilla sp.). 


\section{HASIL}

Karakteristik Aeromoas. Pengujian secara konvensional (biokimia) telah dilakukan untuk mengidentifikasi berbagai jenis bakteri Aeromonas pada ikan sidat
(Anguilla sp). Karakteristik biokimia bakteri Aeromonas pada ikan sidat yang dilalulintaskan melalui bandar udara Mutiara Sis Aljufri Palu dapat dilihat pada Tabel 1 berikut:

Tabel 1. Karakteristik Biokimia Bakteri Aeromonas Pada Ikan Sidat (Anguilla sp.) yang dilalulintaskan Melalui Bandar Udara Mutiara Sis Aljufri Palu

\begin{tabular}{llll}
\hline \multicolumn{1}{c}{ Karakteristik } & \multicolumn{1}{c}{ A. hydrophilla } & \multicolumn{1}{c}{ A. sobria } & \multicolumn{1}{c}{ A. caviae } \\
\hline Gram & Negatif & Negatif & Negatif \\
Betuk sel & Batang & Batang & Batang \\
Katalase & Positif & Positif & Positif \\
Oksidase & Positif & Positif & Positif \\
Motility & Motil & Motil & Motil \\
Indol & Positif & Positif & Positif \\
Ornithin & Negatif & Negatif & Negatif \\
Lysin decarboxylase & Negatif & Negatif & Negatif \\
L arginin & & & \\
Aesculin & Positif & Positif & Positif \\
OF & Positif & Negatif & Positif \\
Methyl red & Fermentatif & Fermentatif & Fermentatif \\
L arabinosa & Positif & Negatif & Positif \\
Glukosa/gas & Negatif & Negatif & Positif \\
TCBS Agar & Positif/gas & Positif/gas & Positif/no gas \\
Rs Agar & Growth & No growth & No growth \\
& Growth/pigmen kuning & Growth/no pigment & Growth/no pigment \\
\hline
\end{tabular}

Intensitas Aeromonas. Intensitas bakteri Aeromonas pada ikan sidast (Anguilla sp.) yang dilalulintaskan melalui Bandar Udara
Mutiara Sis Aljufri Palu pada bulan Maret hingga Desember tahun 2014 disajikan pada gambar 1 berikut:

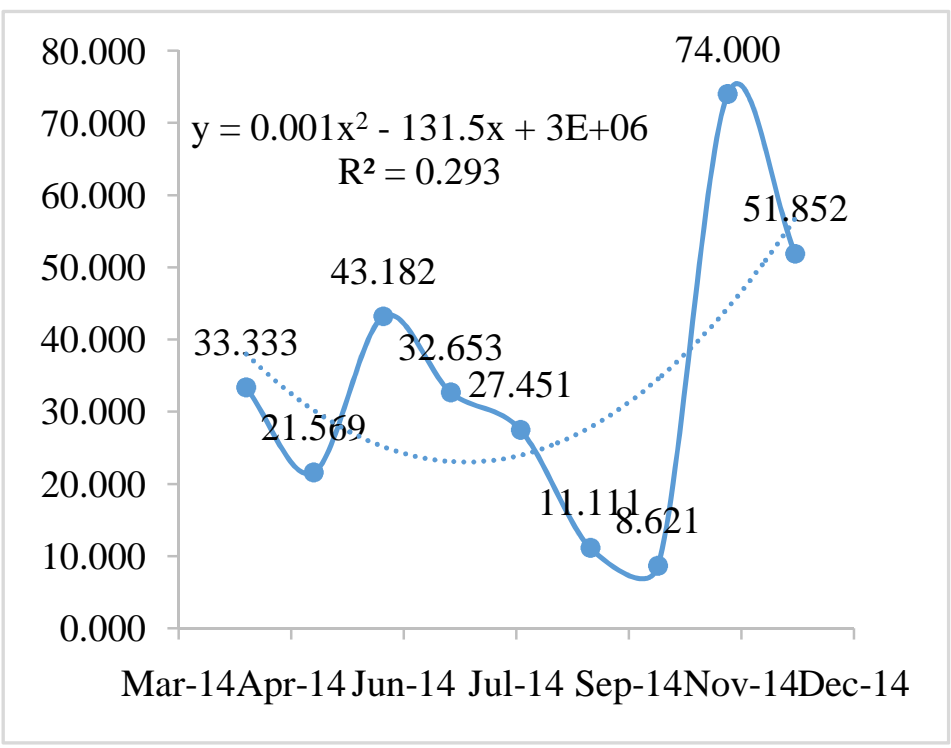

Gambar 1. Variasi bulanan serangan Aeromonas pada sidat (Anguilla sp.)

Terlihat pada gambar 1, bahwa persentase Aeromonas tertinggi pada bulan
November $(74,00 \%)$ dan terendah pada bulan Oktober $(8,26 \%)$. Penurunan intensitas 
serangan terjadi berturut-turut pada bulan Juni $(43,18 \%)$, Juli $(32,65 \%)$, Agustus $(27,45 \%)$, September $(11,00 \%)$, dan Oktober $(8,26 \%)$. Walaupun persentase keberadaan Aeromonas memiliki nilai regresi yang lemah dengan waktu observasi $(29,39 \%)$, namun ada indikasi bahwa keberadaan Aeromonas sangat di pengaruhi oleh frekuensi lalulintas pengiriman.

Dari 396 ekor sidat yang telah diuji, telah diidentifikasi bahwa 128 diantaranya ditemukan bakteri genus Aeromonas. Spesies dari genus Aeromonas yang berhasil di identifikasi antara lain: Aeromonas hydrophilla, Aeromona sobria, dan Aeromonas caviae. Karakteristik biokimia yang membedakan ketiga spesies tersebut adalah: RS agar, TCBS agar, Gas pada glukosa, L arabinosa, Methyl red (MR), dan Aesculin.

Intensitas serangan berbagai spesies Aeromonas. Intensitas masing-masing spesies bakteri Aeromonas pada ikan sidat yang dilalulintaskan melalui Bandar udara Mutiara Sis Aljufri Palu dapat dilihat pada gambar 2 berikut:

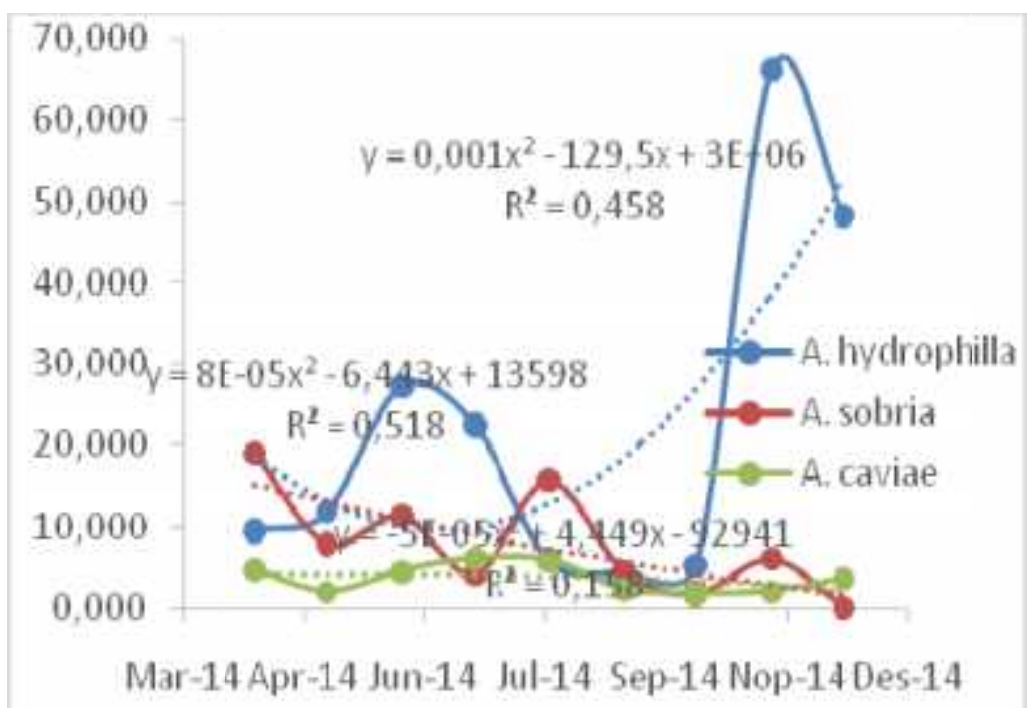

Gambar 2. Intensitas serangan Aeromonas pada Ikan sidat (Anguilla sp.) berdasarkan spesies

Intensitas serangan bakteri Aeromonas sobria memperlihatkan kecenderungan penurunan intensitas selama 9 bulan observasi. Pada bulan Agustus memperlihatkan puncak intensitas serangan, namun nilai regresi masih memperlihatkan hubungan yang cukup kuat sebesar 51,82\% antara intensitas serangan dengan waktu observasi.

Diantara 3 spesies Aeromonas yang diidentifikasi, Aeromonas hydrophilla adalah yang paling dominan $(66,41 \%)$. Persentase Aeromonas sobria dan Aeromonas caviae yang diperoleh masing-masing 22,66\% dan 10,94\%. Intensitas Aeromonas caviae selama observasi cenderung memperlihatkan intensitas yang sama. Intensitas tertinggi pada bulan Juli $(6,122 \%)$ dan terendah pada bulan Oktober $(1,72 \%)$.

Hubungan antara waktu pengamatan dan intensitas serangan $A$. caviae memperlihatkan hubungan yang paling lemah $(15,86 \%)$ diantara tiga spesies yang telah diidentifikasi.

\section{PEMBAHASAN}

Buchanan dan Gibbons dalam Bergey's Manual of Determinative Bacteriology (1974) mengelompokkan Aeromonas hydrophilla menjadi 3 subspesies, antara lain: hydrophilla, anaerogenes, dan proteolitica. Perbedaan ketiga spesies dapat dilihat pada tabel 2. 
Tabel 2. Perbedaan karakteristik bakteri Aeromonas hydrophilla berdasarkan, subspesies dan biotype (Buchanan RE dan Gibbons, 1974).

\begin{tabular}{|c|c|c|c|}
\hline \multirow[t]{2}{*}{ Karakteristik } & \multicolumn{3}{|c|}{$\begin{array}{c}\text { Aeromonas hydrophilla } \\
\text { Subspesies }\end{array}$} \\
\hline & hydrophilla & anaerogenes & proteolitica \\
\hline $\begin{array}{l}\text { Tumbuh pada Nutrient broth } \\
37^{\circ} \mathrm{C}\end{array}$ & + & + & + \\
\hline Pigmen cokelat pada TSA & - & - & - \\
\hline $\begin{array}{l}\text { Asam amino } \\
\text { L Arginin }\end{array}$ & & & \\
\hline L Asparagin & + & + & + \\
\hline L Histidin & + & + & + \\
\hline L Glutamin & + & + & + \\
\hline L Serine & + & $+^{\mathrm{c}}$ & + \\
\hline L Alanin & $+^{\mathrm{c}}$ & $\mathrm{d}$ & + \\
\hline Nutrient broth dengan $7,5 \%$ & $\mathrm{~d}$ & $\mathrm{~d}$ & + \\
\hline $\mathrm{NaCl}$ & + & + & + \\
\hline Produksi gas pada gliserol & & & \\
\hline $\begin{array}{l}\text { Produksi gas pada glukosa } \\
\text { Indole }\end{array}$ & + & + & + \\
\hline $\begin{array}{l}\text { Lysin dekarboksilase } \\
\text { Voges Proskauer }\end{array}$ & + & - & - \\
\hline Galaktosa & + & + & + \\
\hline Sukrosa & - & - & + \\
\hline Manitol & & & \\
\hline Arabinosa & + & + & + \\
\hline Aesculin & + & + & - \\
\hline & $\mathrm{d}$ & + & - \\
\hline & + & + & + \\
\hline & $\mathrm{d}$ & + & - \\
\hline & $\mathrm{d}$ & $\mathrm{d}$ & - \\
\hline
\end{tabular}

Aeromonas menyebabkan berbagai kondisi patologis seperti: akut, kronik, dan infeksi yang tidak tampak. Motil Aeoromonas memiliki tingkat patogenitas yang berbeda, keganasan penyakit dipengaruhi oleh faktorfaktor yang saling berhubungan seperti virulensi, jenis virulensi, tingkat stress pada populasi ikan, kondisi fisiologi inang, dan genetik.

Meskipun tidak semua karakteristik yang membedakan subspesies A. hydrophilla diamati, namun penelitian ini menunjukkan bahwa sebagian karakteristik mengarah pada Aeromonas hydrophila subspesies hydrophilla. Perbedaan karakteristik nampak pada pengujian gas pada glukosa (gas positif) dan lysin dekaboxilase (negatif). Hasil pengujian Aesculin (positif) menunjukkan bahwa A. hydrophilla bukan merupakan subspesies proteolitica, pengujian L arabinosa (negatif) juga memberikan petunjuk bahwa $A$. hydrophilla pada sidat yang diuji bukan berasal dari subspesies anaerogenes.

Permintaan pasar terhadap sidat pada November 2014 cukup tinggi. Tercatat, sebanyak 50 kali frekuensi lalulintas (SKIPM Palu, data tidak terpublikasi). Berdasarkan pengamatan peneliti, pengumpul ikan sidat di Kota Palu memiliki fasilitas kolam yang terbatas, sehingga pada waktu tertentu pengumpul harus menampung sidat di kolam dengan kepadatan yang tinggi. Pada kepadatan tinggi sidat lebih mudah mengalami stress.

A. hydrophila telah dihubungkan dengan beberapa penyakit pada ikan antara lain: lesi pada ekor, kerusakan pada insang dan hemoragik septikemia. Bakteri A. hydrophilla 
menyebabkan penyakit red disease pada kolam budidaya sidat. Infeksi bakteri $A$. hydrophilla pada ikan sidat dapat mengakibatkan hemoragi pada permukaan tubuh. Bakteri A. hydrophila merupakan penyebab penyakit hemoragic septicaemia yang juga disebut sebagai Motile Aeromonas Septicaemia (MAS). Bakteri ini dikenal bersifat oportunis karena akan menyerang saat ikan mengalami stres. Gejala ikan yang terinfeksi MAS bervariasi tetapi umumnya ditandai oleh adanya pendarahan (hemoragik) pada kulit, insang, rongga mulut, borok pada kulit, dan bola mata menonjol (exopthalmia) dan perut kembung serta ikan lemas dan sering di permukaan atau dasar kolam (Jayavignesh et al., 2011).

Meskipun angka kematian yang disebabkan oleh Aeromonas tergolong rendah (<10\%) (Floyd, 2002), namun bakteri ini dapat menyerang ikan sepanjang waktu. Pada beberapa contoh, faktor yang berpengaruh diantaranya adalah stress, stress menyebabkan ikan mudah terinfeksi bakteri. Keadaan stress juga dapat disebabkan oleh buruknya kualitas air, kepadatan yang berlebih, dan penanganan yang buruk.

\section{KESIMPULAN}

Aeromonas yang diidentifikasi pada ikan sidat (Anguilla sp.) yang dilalulintaskan melalui bandar udara Mutiara Sis Aljufri Palu antara lain: Aeromonas hydrophilla subspesies hydrophilla, Aeromonas sobria, dan Aeromonas caviae. Intensitas tertinggi berturut-turut adalah $A$. hydrophilla (85 kali), A. sobria (29 kali), dan A. caviae (14 kali). Aeromonas sobria selama bulan April hingga Desember 2014 memperlihatkan penurunan intensitas serangan. Intensitas A. caviae memiliki kecenderungan serangan yang sama sepanjang tahun 2014, dan tertinggi pada bulan Juli $(6,12 \%) . \quad A$. hydrophilla memperlihatkan peningkatan intensitas serangan dan tertinggi pada bulan Novermber (74\%). Pengumpul sidat disarankan untuk mengurangi padat tebar per satuan luas kolam terutama saat stok sidat melimpah.

\section{DAFTAR PUSTAKA}

Buchanan RE dan Gibbons NE. 1974. Bergey's Manual of Determinative Bacteriology. Edisi Delapan. The William \& Wilkins Company. USA: Baltimore.

Buller NB. 2004. Bacteria from Fish and Other Aquatic Animals. A Practical Identification Manual. South Perth, Western Australia: CABI Publishing. pp 390.

Floyd FR. 2002. Aeromonas Infections, FA14 Document, IFAS Extension, Fisheries and Aquatic Sciences Department, Florida Cooperative Extension Service, Institute of Food and Agricultural Sciences. Florida: University of Florida.

Gardenia L, Isti K, Hambali S, dan Tatik M. 2010. Aplikasi Deteksi Aeromonas hydrophilla Penghasil Aerolysin dengan Menggunakan Polymerase Chain Reaction (PCR). [Prosiding] Forum Inovasi Teknologi Akuakultur. Jakarta: Pusat Riset Perikanan Budidaya. hal 17.

Jayavignesh V, Kannan SK, dan Bhat AD. 2011. Biochemical characterization and cytotoxicity of the Aeromonas hydrophila isolated from Catfish. Arch. Appl. Sci. Res. vol 3(3): 85-93. 